ORIGINAL

ISSN 0103-5150

Fisioter. Mov., Curitiba, v. 33, e003367, 2020

DOI: http://dx.doi.org/10.1590/1980-5918.032.A066

Licensed under a Creative Commons attribution

\title{
Construction and validation of an algorithm to prevent and treat upper extremity lymphedema
}

\section{Construção e validação de um algoritmo para prevenção \\ e tratamento de linfedema de membros superiores}

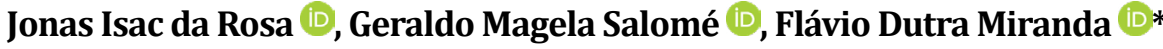

Universidadedo Vale do Sapucai (UNIVAS), Pouso Alegre, MG, Brazil

\begin{abstract}
Introduction: Some health professionals have difficulty treating and preventing upper extremity lymphedema (UEL), demonstrating the need for evidence-based educational technology, such as algorithms. These algorithms should be simple, clear and direct, providing a comprehensive portrait of the care process. Objective: Construct and validate an algorithm to prevent and treat upper extremity lymphedema Method: In order to construct the algorithm, an integrative literature review was conducted in the Health Sciences, SciELO, LILACS and MEDLINE databases. The algorithm was evaluated by 27 physiotherapists and validated using the Delphi method. Statistical analysis was carried out using the content validity index (CVI). Results: In the first assessment, the judges classified the algorithm as "Inadequate" or "Adequate"; following corrections made according to their suggestions, the algorithm was reassessed as "Adequate" or "Completely adequate". The content validity index was 0.95 at the former and 1.0 at the latter. Conclusion: Following an integrative literature review, an algorithm to treat and prevent upper extremity lymphedema
\end{abstract}

*JIR: MS, e-mail: jonasisac.fisio@gmail.com GMS: PhD, e-mail:salomereiki@univas.edu.br FDM: MS, e-mail: flaviodutramiranda@terra.com.br 
was constructed and validated by experienced professionals, exhibiting interrater agreement in the second assessment.

Keywords: Lymphedema. Physical Therapy. Algorithms.

\section{Resumo}

Introdução: Alguns profissionais apresentam dificuldades para tratar e prevenir o linfedema de membros superiores. Sendo assim, há a necessidade de desenvolver tecnologia educativa desenvolvido com embasamento cientifico, por exemplo, algorítmo. Os algoritmos devem ser simples, claro, diretos e, que conferem uma visão completa do processo de cuidado devem ser desenvolvido.Objetivo: Construir e validar um algoritmo para tratamento e prevenção de linfedema de membros superiores. Método: Para a construção do algoritmo, foi realizada revisão integrativa da literatura nas bases de dados das Ciências da Saúde, SciELO, LILACS, MEDLINE. A avaliação do algoritmo foi feita por 27 fisioterapeutas. Para a validação do algoritmo, recorreu-se à técnica de Delphi. A análise estatística utilizada foi o Índice de Validade de Conteúdo. Resultados: Na primeira avaliação, os juízes avaliaram o algoritmo entre "Inadequado" e "Adequado"; após feitas as correções sugeridas pelos avaliadores, o algoritmo foi reenviado, tendo sido avaliado entre "Adequado" e "Totalmente adequado". Com relação ao índice de validade de conteúdo geral, na primeira avaliação, foi 0,95 e, na segunda avaliação, foi 1,0. Conclusão: Após revisão integrativa da literatura, o algoritmo para tratamento e prevenção de linfedema de membros superiores foi construído e validado por profissional com experiência na área, mostrando concordância entre os juízes na segunda avaliação

Palavras-chave: Linfedema. Fisioterapia. Algoritmos.

\section{Introduction}

Lymphedema is the accumulation of fluid and protein in tissue spaces that affects patients with a compromised lymphatic system [1]. It is an important postoperative complication in patients with cancer and results from a buildup of protetin-rich fluid in the interstitium due to disorders of the lymphatic system, most commonly affecting the upper extremities $[1,2]$.

Lymphedema after mastectomy occurs in around 20 to $30 \%$ of cases, with a prevalence of 15 to $30 \%$. Determining factors include extension of axilliary lymph node dissection; radiotherapy to the axilla and supraclavicular fossa; chemotherapy; advanced stage at diagnosis; postoperative infection; lymphangitis and cellulite; obesity; advanced age; delay in closing the wound; presence of seroma; node-positive disease; delayed wound healing; compression dressing and immobilization of the limb homolateral to the surgery. This limits movement, which, over a 7-day postoperative period, is sufficient to decrease lymphatic flow by $40 \%$ due to the trauma of surgery and/or patient immobility [2-4].
It is vital that patients submitted to a mastectomy be seen by a physiotherapist after surgery, in order to control postoperative pain, prevent or treat lymphedema and postural changes, promote muscle relaxation, maintain the range of motion of the affected arm, improve the appearance and texture of the scar, and prevent or treat adhesions. The therapeutic resource used is kinesiotherapy (rehabilitation through exercise) and guidance for activities of daily living [1].

Complete decongestive therapy (CDT) is the gold standard for lymphedema management and consists of four essential components: skin and wound care; manual lymphatic drainage; compression bandages and lymphokinetic exercise [3]. In the acute or outpatient stage of lymphedema, the recommended exercise intensity is at least three times a week, supervised by a physiotherapist; however, exercises should ideally be performed every day [5].

In the second stage, also known as the maintenance phase, patients are advised to continue all the techniques used in the acute stage and resume their 
normal routine, regularly performing all the prescribed exercises at home. Studies show that most patients revert back to the initial phase because they fail to follow the treatment plan at home [3-5].

In order for physiotherapists to provide the necessary guidance, they must have technical and scientific knowledge and be capable of developing effective, straightforward and easily accessible educational resources (booklets, manuals, protocols and algorithms) [6-9].

In the field of health, algorithms are simple, direct and easily accessible tools that provide a comprehensive portrait of the care process, serving as a guide for decision making, particularly those of a more complex nature [10-13].

A number of validated studies have investigated algorithms aimed at care processes, guiding clinical decisions and treating acute and chronic wounds, with recommendations based on practical research [13-14].

The creation of an algorithm for patients with upper extremity lymphedema (UEL) after mastectomy is unprecedented in the field of physiotherapy. This approach is scientifically and socially relevant in that it provides access to information and specific treatment modalities and helps control patient evolution. The present study aims to construct and validate an algorithm to prevent and treat upper extremity lymphedema.

\section{Method}

This study involves technology production, with a methodological development approach.

Constructing and algorithm to treat and prevent upper extremity lymphedema

Phase one "Bibliographic research"

An integrative literature review was conducted to construct the algorithm, searching for articles published in English, Spanish and Portuguese between 2009 and 2019 on Health Sciences databases as well as the Cochrane Library, Scientific Eletronic LibraryOnline (SciELO), Latin American and Caribbean Health Sciences Literature (LILACS) and the United States National Library of Medicine (MEDLINE). The search strategy for each language was determined by combining the (1) lymphedema and (2) physiotherapy with the Boolean operator "AND".

The inclusion criteria adopted to select articles for the integrative review were primary studies directly linked to the topic; articles available in full with no time restrictions, since the goal was to gather all the studies that met the established criteria. Excluded were book chapters, theses, dissertations, monographs, technical reports, reference articles and those identified as beyond the objective of the study after reading the abstract. Articles classified as level 6 (evidence based on expert opinion) were also excluded.

The evidence level of the studies selected was categorized into six levels, as follows [15]:

Level 1: evidence resulting from meta-analyses of multiple randomized controlled trials;

Level 2: evidence obtained from individual experimental studies;

Level 3: evidence from quasi-experimental studies;

Level 4: evidence from descriptive (nonexperimental) or qualitative studies;

Level 5: evidence from case reports or experience;

Level 6: evidence based on expert opinion.

A total of 681 articles were identified by the combination of descriptors, but only 36 were included in the analysis (Figure 1).

Articles that described UEL and physiotherapy in patients after mastectomy were selected after the abstracts were read. Based on this information, an algorithm was created to treat and prevent upper extremity lymphedema in this population in five stages, as follows:

Stage one: bibliographic review

Stage two: risk factors for patients with UEL after mastectomy.

Stage three: assessment and staging of UEL.

Stage four: standardizing care to prevent UEL in patients after mastectomy.

Stage five: standardizing exercises prescribed for individuals with UEL following mastectomy.

The correct skin care technique was described and instructions for patients were defined. The manual lyphatic drainage technique was also established, detailing the removal of fluid from preserved lymph nodes opposite the affected arm, with subsequent definition of movement from the proximal to distal area of the arm. 


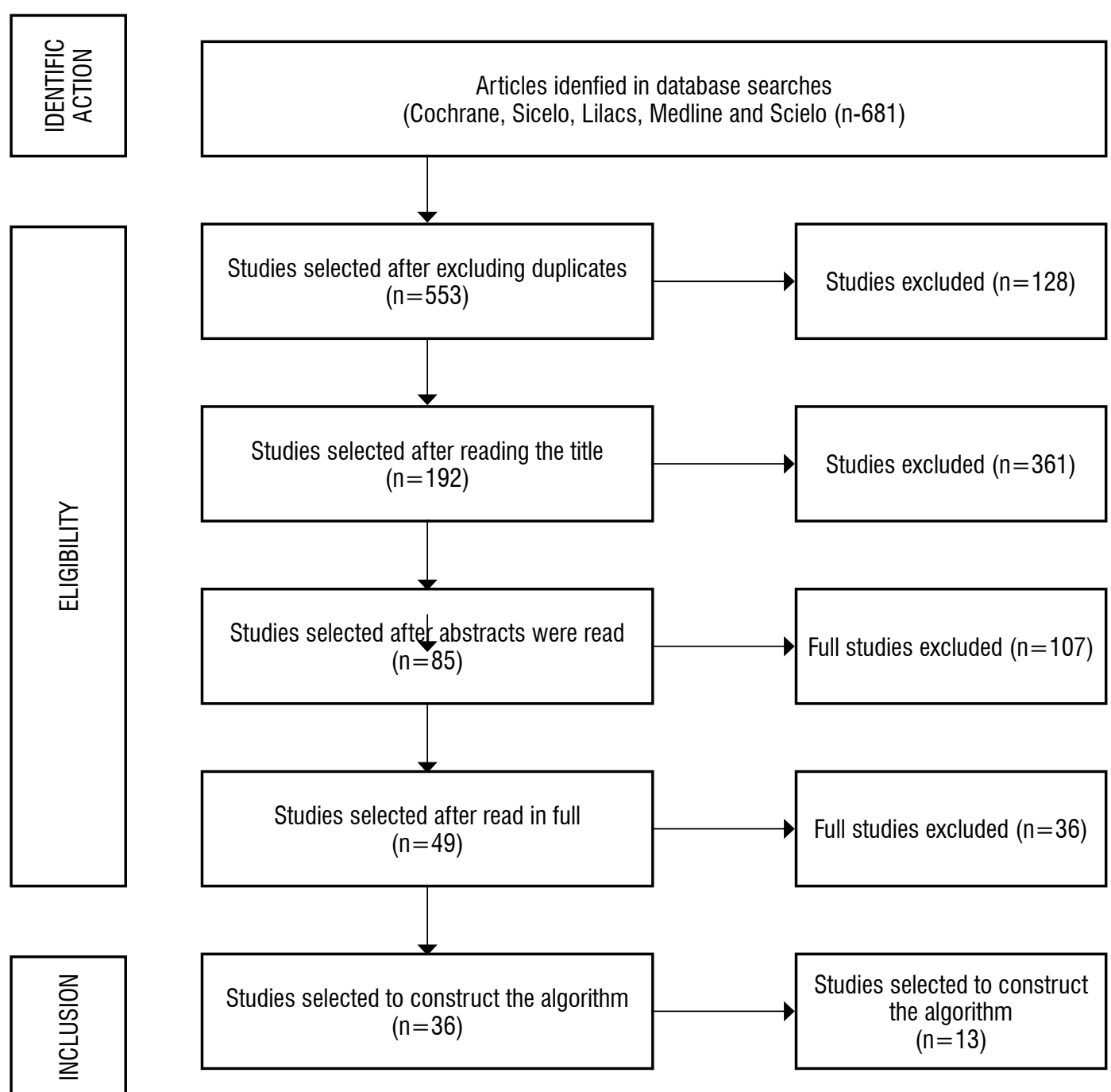

Figure 1 - Flowchart of the identification, selection and inclusion of studies from the integrative literature review to compile the manual.

Validating the algorithm to treat and prevent upper extremity lymphedema

The study was conducted at Universidade do Vale do Sapucai's Hospital das Clínicas Samuel Libânio. Thirty physiotherapists took part in the study.

Inclusion criteria for the judges were being 18 or older; holding an undergraduate degree in physiotherapy for more than 12 months and havng at least 12 months' experience in the field.

Exclusion criteria were physical therapists who agreed to participate but did not complete and/or submit the assessment questionnaire within the 30-day deadline and those who failed to clearly and objectively answer all the questions.

A 20-question survey was compiled, divided into three parts: information on the assessor, with four questions; algorithm assessment, containing six questions; and assessor opinion on context, consisting of ten questions.

The physiotherapists evaluated the following aspects of the algorithms: thematic content, graphic presentation, sequencing, clarity, lymphedema staging, risk factors, identification, prevention, treatment and final UEL 
considerations. To that end, a 4-point Likert scale was used, with the response options "adequate", "completely adequate", "inadequate" and "somewhat adequate". The opinion-based questions were rated on a dichotomous scale ("yes" and "no" answers), with instructions on optional descriptive answers for each item.

The invitation letter consisted of an initial presentation and details on the research topic, with a definition of the objective regarding UEL, as well as the report from the Research Ethics Committee of the Dr. José Antônio Garcia Coutinho College of Health Sciences and explanations on the importance of professional assessors to the study. Additionally, the questions answered by the assessors were explained, as well as the thirty-day deadline to complete and return the questionnaires for each assessment round, counted from the date on which they were sent to respondents.

The algorithm validation process was as follows:

1) Selecting the professional assessors by checking the personal or email contacts of the study participants registered at the abovementioned institutions.

2) Sending the instruments to the assessor by email or hand delivering the printed questionnaire. The participants read and signed the informed consent form, providing their full name and profession and agreeing to participate in the study. Those who received the questionnaire by email printed and filled it out, then signed, scanned and resent it.

3) In data analysis, responses classified as "adequate" and "completely adequate" were considered valid, and "inadequate" and "somewhat adequate" excluded. The judge's suggestions were analyzed, and recommendations made for items to be deemed valid. These recommendations are indicated in previous studies on the assessment method [16]. Questions classified as 1 (inadequate) or 2 (somewhat adequate) were resubmitted to the judges in the second assessment round based on the recommendations given and obtained $100 \%$ approval. This procedure is in line with the Delphi method, which uses the opinions of expert judges with specific knowledge in a given area [17]. The content of questionnaires is analyzed by a panel of experts, with the goal of achieving 50 to $100 \%$ agreement. There are typically two to three assessment rounds [17-18].
Two groups were used for this process, one consisting of the researchers, responsible for contacting the respondents, compiling the initial questionnaire, analyzing the data and constructing the remaining questionnaires, and the other containing the expert judges.

The data obtained were tabulated using Microsoft Excel (2010) and quantitatively analyzed under the supervision of NRM Consultoria Estatística. Statistical analysis was performed with the Statistical Package for the Social Sciences (SPSS) version 2 and the statistical tool applied was the content validity index (CVI).

The CVI measures the proportion or percentage of experts who agree on certain aspects of an instrument and its items and is widely used in the field of health [19]. Agreement and representativeness are rated on a Likert scale, with responses varying from relevant to not representative or clear to not clear, for example. The questionnaire used here offered four possible answers, with only one marked per question, namely inadequate, somewhat adequate, adequate or completely adequate, as well as a field at the end for judges to insert their own suggestions and opinions.

In order to validate the algorithm, a field was provided after each item for assessors to suggest improvements to the algorith. The CVI was calculated considering the number of "adequate" and "completely adequate" answers for each item divided by the total number of responses. The CVI of a valid questionnaire should be greater than or equal to 0.78 when six or more experts participate.

\section{Results}

Table 1 and 2 show the algorithm content assessment, using the Delphimethod. In the firstassessment, the experts evaluated the algorithm as "inadequate" or "completely adequate". Following corrections made according to their suggestions, it was assessed as "adequate" or "completely adequate".

According to Table 3, the item CVI in the first assessment varied from 0.88 to 1.0 , with an overall (scale-level) value of 0.95 .

Following corrections made based on the experts' suggestions, the algorithm was reevaluated and item and scale CVIs of 1.0 and 1.0, respectively were obtained.

These results indicate interrater agreement on algorithm (Figure 2). content in the second assessment. 
Table 1 - First evaluation of the content of the algorithm for the treatment and prevention of upper limb lymphedema in patients with hair mastectomy, Delphi method

\begin{tabular}{|c|c|c|c|c|c|c|c|c|c|c|}
\hline \multicolumn{11}{|c|}{$\begin{array}{l}\text { Delphi Method } \\
\text { First Assessment }\end{array}$} \\
\hline \multirow[t]{2}{*}{ Question } & \multicolumn{2}{|c|}{ Inadequate } & \multicolumn{2}{|c|}{$\begin{array}{l}\text { Partially } \\
\text { adequate }\end{array}$} & \multicolumn{2}{|c|}{ Adequate } & \multicolumn{2}{|c|}{$\begin{array}{c}\text { Fully } \\
\text { adequate }\end{array}$} & \multicolumn{2}{|c|}{ Doesn't Apply } \\
\hline & $\mathbf{N}$ & $\%$ & $\mathbf{N}$ & $\%$ & & $\%$ & $\mathbf{N}$ & $\%$ & $\mathbf{N}$ & $\%$ \\
\hline Graphic presentation & 0 & 0 & 1 & 7.69 & 8 & 30.70 & 17 & 65.00 & 0 & 0 \\
\hline Sequencing & 0 & 0 & 2 & 7.69 & 6 & 23.00 & 18 & 69.20 & 0 & 0 \\
\hline Clarity & 0 & 0 & 2 & 7.69 & 8 & 30.70 & 16 & 61.00 & 0 & 0 \\
\hline Easy application & 0 & 0 & 2 & 7.69 & 6 & 23.00 & 18 & 69.20 & 0 & 0 \\
\hline Vocabulary & 0 & 0 & 1 & 3.84 & 13 & 50.00 & 12 & 46.15 & 0 & 0 \\
\hline Currentness & 0 & 0 & 1 & 3.84 & 8 & 30.70 & 17 & 65.00 & 0 & 0 \\
\hline Description of anamnesis & 0 & 0 & 0 & 0 & 5 & 19.23 & 21 & 80.70 & 0 & 0 \\
\hline $\begin{array}{l}\text { Description of the clinincal } \\
\text { assessment } \\
\text { Description of }\end{array}$ & 0 & 0 & 0 & 0 & 6 & 23.00 & 20 & 77.00 & 0 & 0 \\
\hline $\begin{array}{l}\text { the assessment of the } \\
\text { affected arm }\end{array}$ & 0 & 0 & 0 & 0 & 6 & 23.00 & 20 & 77.00 & 0 & 0 \\
\hline Range of motion description & 0 & 0 & 0 & 0 & 6 & 23.00 & 20.0 & 77.00 & 0 & 0 \\
\hline Description of perimetry & 0 & 0 & 3 & 11.57 & 3 & 11.57 & 20 & 77.00 & 0 & 0 \\
\hline Description of lymphedema & 0 & 0 & 2 & 7.69 & 3 & 11.57 & 21 & 80.70 & 0 & 0 \\
\hline Lymphedema staging & 0 & 0 & 0 & 0 & 4 & 15.38 & 21 & 80.70 & 1 & 0 \\
\hline $\begin{array}{l}\text { Treatment for grade } 1 \\
\text { lymphedema }\end{array}$ & 0 & 0 & 0 & 0 & 6 & 23.00 & 19 & 73.00 & 1 & 0 \\
\hline $\begin{array}{l}\text { Treatment for grade } 2 \\
\text { lymphedema }\end{array}$ & 0 & 0 & 0 & 0 & 8 & 30.70 & 16 & 61.00 & 0 & 0 \\
\hline $\begin{array}{l}\text { Treatment for grade } 3 \\
\text { Iymphedema }\end{array}$ & 0 & 0 & 2 & 7.69 & 6 & 23.00 & 18 & 69.20 & 0 & 0 \\
\hline
\end{tabular}

Table 2 - Partial correlation coefficients between anthropometric variables, biological maturation and Walking Backward (WB) controlled by chronological age.

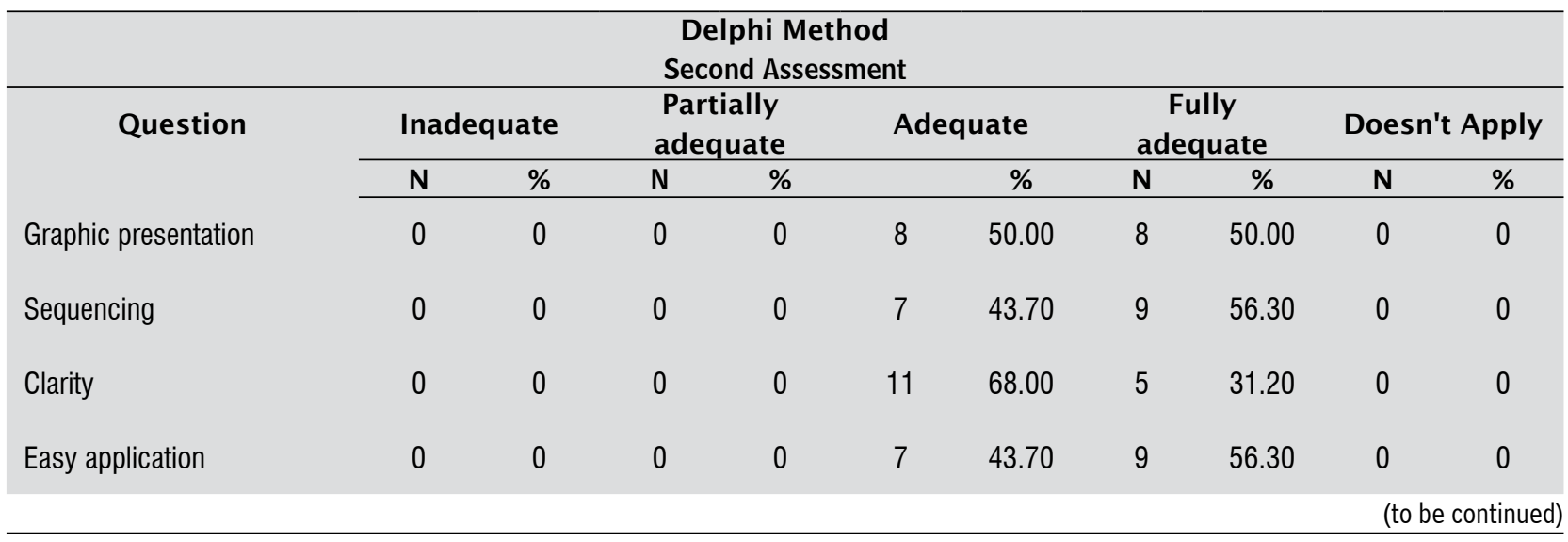




\begin{tabular}{|c|c|c|c|c|c|c|c|c|c|c|}
\hline & & & & & & & & & \multicolumn{2}{|c|}{ (conclusion) } \\
\hline Vocabulary & 0 & 0 & 0 & 0 & 12 & 75.00 & 4 & 25.00 & 0 & 0 \\
\hline Currentness & 0 & 0 & 0 & 0 & 7 & 43.70 & 9 & 56.30 & 0 & 0 \\
\hline Description of anamnesis & 0 & 0 & 0 & 0 & 7 & 43.70 & 9 & 56.30 & 0 & 0 \\
\hline $\begin{array}{l}\text { Description of the clinincal } \\
\text { assessment } \\
\text { Description of }\end{array}$ & 0 & 0 & 0 & 0 & 7 & 43.70 & 9 & 56.30 & 0 & 0 \\
\hline $\begin{array}{l}\text { the assessment of the } \\
\text { affected arm }\end{array}$ & 0 & 0 & 0 & 0 & 7 & 43.70 & 9 & 56.30 & 0 & 0 \\
\hline Range of motion description & 0 & 0 & 0 & 0 & 3 & 18.70 & 13 & 81.20 & 0 & 0 \\
\hline Description of perimetry & 0 & 0 & 0 & 0 & 3 & 18.70 & 13 & 81.20 & 0 & 0 \\
\hline Description of lymphedema & 0 & 0 & 0 & 0 & 4 & 25.00 & 12 & 75.00 & 0 & 0 \\
\hline Lymphedema staging & 0 & 0 & 0 & 0 & 4 & 25.00 & 12 & 75.00 & 0 & 0 \\
\hline $\begin{array}{l}\text { Treatment for grade } 1 \\
\text { lymphedema }\end{array}$ & 0 & 0 & 0 & 0 & 7 & 43.70 & 9 & 56.30 & 0 & 0 \\
\hline $\begin{array}{l}\text { Treatment for grade } 2 \\
\text { lymphedema }\end{array}$ & 0 & 0 & 0 & 0 & 8 & 50.00 & 8 & 50.00 & 0 & 0 \\
\hline $\begin{array}{l}\text { Treatment for grade } 3 \\
\text { lymphedema }\end{array}$ & 0 & 0 & 1 & 6.30 & 7 & 43.70 & 8 & 50.00 & 0 & 0 \\
\hline
\end{tabular}

Table 3 - Content validity index of the questions used to assess the algorithm for treating and preventing upper extremity lymphedema in patients after mastectomy using the Delphi method

\begin{tabular}{lcc}
\hline \multicolumn{1}{c}{ Question } & \multicolumn{2}{c}{ Content validity index } \\
& First Assessment & Second Assessment \\
\hline Graphic presentation & 0.96 & 01 \\
Sequencing & 0.92 & 01 \\
Clarity & 0.92 & 01 \\
Easy application & 0.92 & 01 \\
Vocabulary & 0.96 & 01 \\
Currentness & 0.96 & 01 \\
Description of anamnesis & 1.00 & 01 \\
Description of the clinincal assessment & 1.00 & 01 \\
Description of & 1.00 & 01 \\
the assessment of the affected arm & 0.92 & 01 \\
Range of motion description & 0.88 & 01 \\
Description of perimetry & 0.88 & 01 \\
Description of lymphedema & 0.96 & 01 \\
Lymphedema staging & 0.96 & 01 \\
Treatment for grade 1 lymphedema & 1.00 & 01 \\
Treatment for grade 2 lymphedema & 0.96 & 98 \\
Treatment for grade 3 lymphedema & 0.95 & - \\
Overall content validity index for the first assessment & - & 1.0 \\
Overall content validity index for the second assessment & & \\
\hline
\end{tabular}




\section{angurimm to prevent anu treal upper extremny tympneuema}

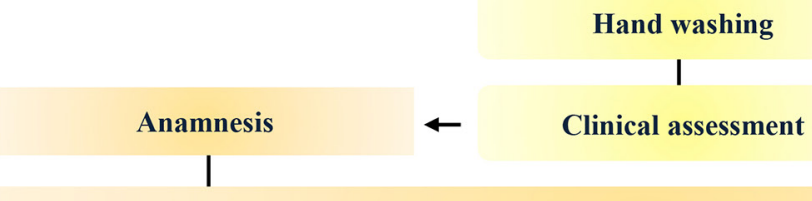

Name, Age, Sex, Marital status, Smoking history, Diabetes, Blood pressure, Last menstruation, Gynecological history, Number of pregnancies, Current disease history, Main complaint and Presence of pain.

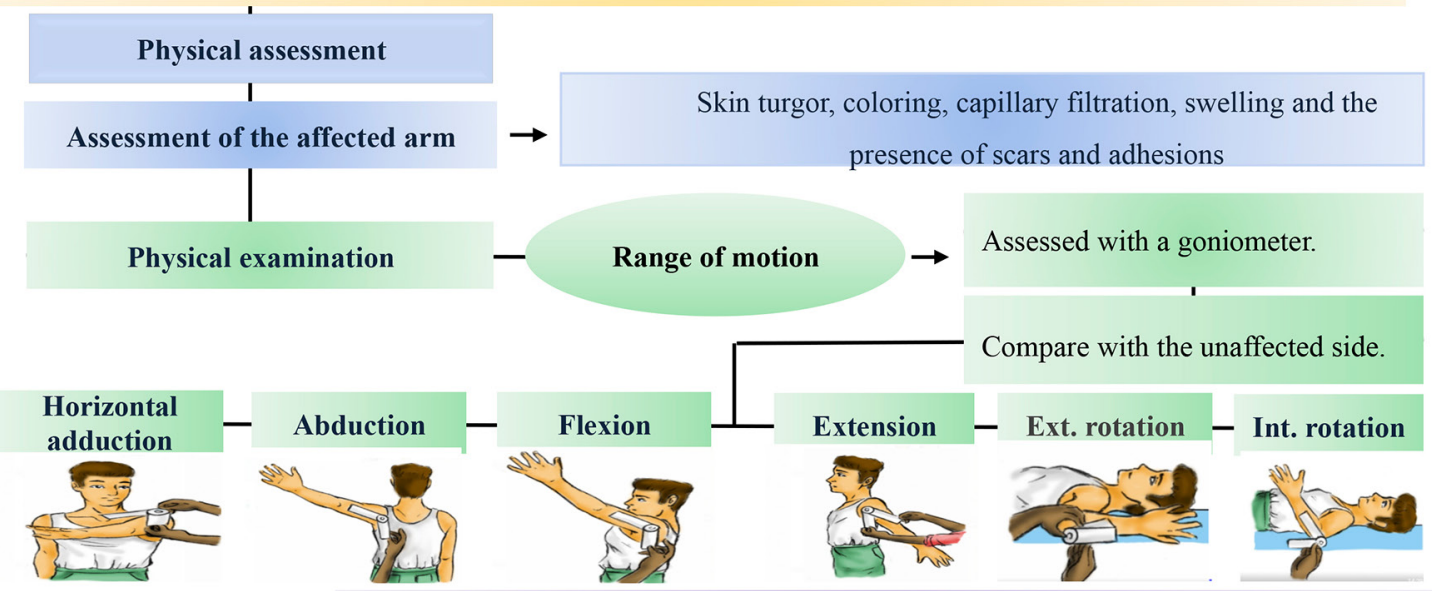

Divide the the distance from the axillary fold to the cubital fossa by 3 and calculate the Perimetry circumference for each third of the limb segment. Next, measure the distance from the (Bilateral) $\rightarrow$ cubital fossa to the wrist and repeat the same procedure. Compare bilaterally and if the difference between limbs is greater than $2 \mathrm{~cm}$, lymphedema is present.

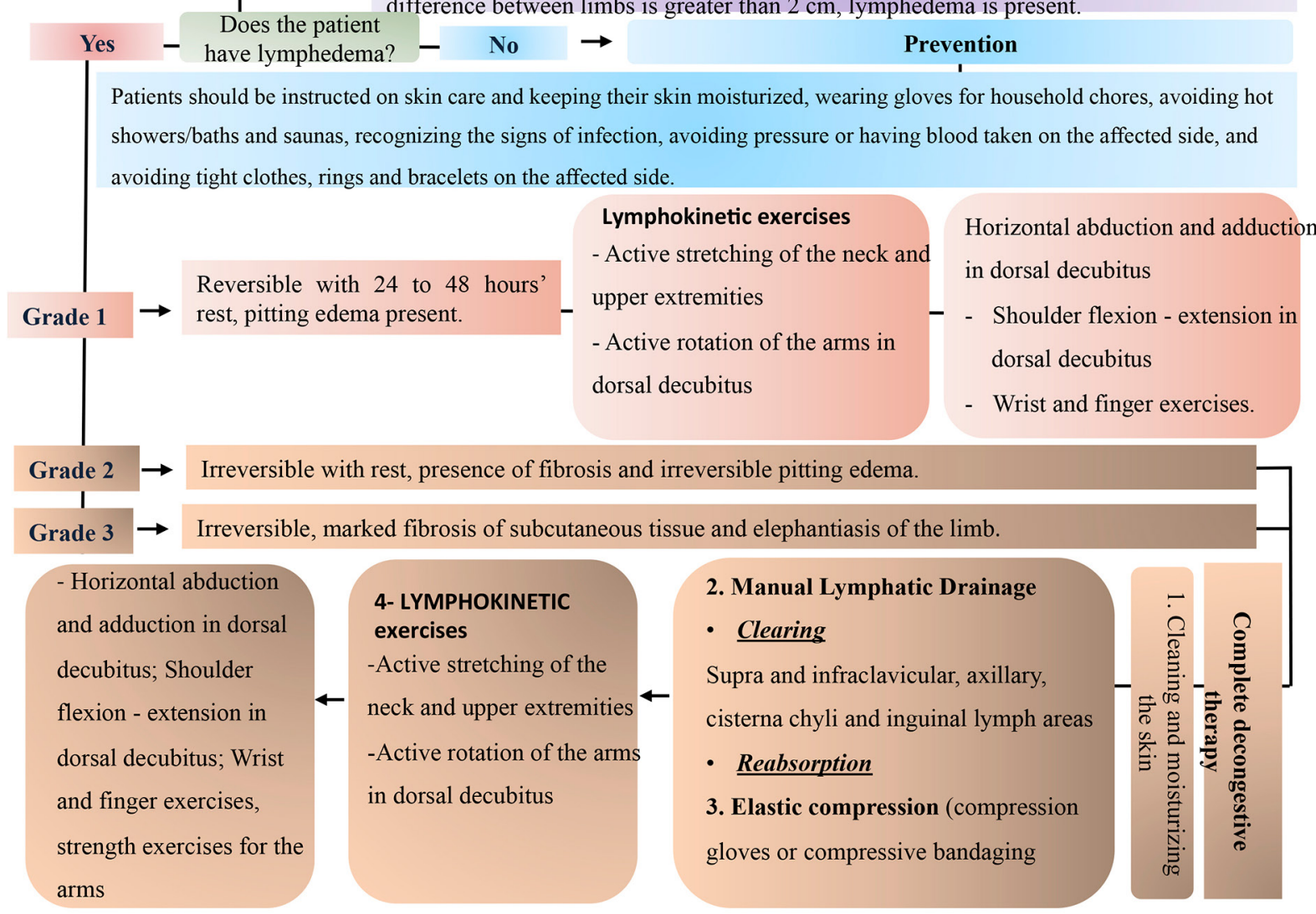

Figure 2 - Algorithm to treat and prevent upper extremity lymphedema in patients after mastectomy.

Reference: References: Fabro et al. [27] and Baracho [28]. 


\section{Discussion}

Lymphedema reduces the tissue distension capacity of structures around the affected limb, causing cutaneous and subcutaneous tissue damage. This not only weakens patients but makes them susceptible to infection [20 - 21].

Complete decongestive therapy (CDT) acts on the pathways of the lymphatic vessels, promoting movement of accumulated liquid from the proximal region and stimulating collateral drainage pathways [20].

CDT is the most widely used technique to minimize lymphedema in postoperative breast cancer patients and consists of decongestion and maintenance. The first phase aims at reducing lymphedema and involves manual lymphatic drainage and intermittent pneumatic compression associated with therapeutic exercises and skin and wound care. Comparison of the cost and efficacy of different techniques has shown that compressive bandaging stands out in both, falling short only in terms of asthetics and comfort according to patient accounts [22].

Another important aspect is physiotherapy training; in theory, all general physical therapists should be able to execute the techniques described in the algorithm.

Physiotherapists play a vital role in treating and restoring the self-esteem of patients with UEL. Preventing and treating this condition is key to improving the physical and psychological health of patients and, consequently, their quality of life. As such, an algorithm was developed to allow physiotherapists to identify risk factors and the appropriate conduct to treat and prevent UEL.

Thealgorithm was constructed based on technological information, an integrative literature review, national and international guidelines and clinical evidence, which provided the necessary technical, clinical and technological framework. The primary objectives should always be ensuring quality care for patients and optimal treatment results for professionals.

The algorithms contribute to guiding decision making on clinincal care, provide scientific rationality and serve as a guide in self-care, prevention and treatment of peristomal skin complications. They also provide information on the best prophylactic-therapeutic strategy to adopt in each clinical assessment by physiotherapists and multiprofessional teams, confirming their proficiency and accuracy as a guiding tool for care. The process of developing an algorithm should include its assessment by a professional with specific knowledge in the area, care practices and proposed therapy $[9,13,23]$.

Algorithm construction should be based on the literature and clinical evidence in order to provide a technical, clinical, technological, administrative and financial framework, with a view to providing optimal care for patients and the best results for institutions [13, 23].

The content of the algorithms developed here was evaluated by experienced physiotherapists using the Delphi method. In the first assessment, most of the experts classified the algorithm content as "inadequate" or "adequate"; however, following corrections made based on their suggestions, the content was deemed "adequate" or "completely adequate". These results indicate good internal consistency for the algorithm content validity questionnaire and corroborate the findings of other authors $[9,13,20,24]$.

Several studies that validated the content of protocols, booklets, applications and algorithms using the Delphi method reported that content correction according to expert suggestions should be evidence-based to ensure better understanding, effectiveness and implementation. This allows professionals to select the best preventive measures and therapies, resulting in safe care with minimal risk and lower costs $[9,13,20,24]$.

With respect to algorithm content validity, the overall CVI in the first and second assessments was 0.91 and 1.0 , respectively, indicating interrater agreement only for the latter and corroborating the results of other authors $[13,20,24]$.

Algorithms are considered important instruments in addressing a variety of problems in the provision and management of health care. Studies validated by scientific evidence are based on technical, organizational and political guidelines and focus on standardizing clinical, surgical and preventive measures $[6,7,25,26]$.

The algorithms developed here provide relevant information to better guide healthcare professionals in treatmentand prevention strategies as well as assessment and decision making for post-mastectomy patients with UEL, resulting in better quality of life for this population. Algorithms are modern information tools that contribute to future advances in the availability of work content as well as palliative care and protocols.

\section{Conclusion}

This study was limited in that the material was not legitimized by the target population. The goal for future 
studies would be to develop an application/software that provides access to treatment and prevention for patients with upper extremity lymphedema after mastectomy.

As such, it can be concluded that, after an integrative literature review, the algorithms were constructed and validated by experienced professionals, with $100 \%$ interrater agreement at the second assessment.

\section{References}

1. Cendron SW, Paiva LL, Darski CC. Fisioterapia complexa descongestiva associada a terapias de compressão no tratamento do linfedema secundário ao câncer de mama: uma revisão sistemática. Rev Bras Cancerol. 2015;61(1):49-58.

2. Luz ND, Lima ACG. Recursos fisioterapêuticos em linfedema pós-mastectomia: uma revisão de literatura. Fisioter Pesqui. 2011;24(1):191-200.

3. Tavares AC, Velar CM, Bueno CS, Bazan M, Brito CMM, Toscano JL. Grupo de Monitoramento do Linfedema: cuidados pós- alta de um programa de reabilitação nos pacientes com câncer de mama. Anais do Congresso Internacional de Humanidades \& Humanização em Saúde; 2014 Mar 31-Apr 1; São Paulo, SP, Brazil. São Paulo: Editora Blucher; 2014.

4. Tacani PM, Camargo RAL, Silva G, Moreira BC, Batista PAN, Montezello D, et al. Fisioterapia descongestiva no linfedema de MMSS pós-mastectomia: estudo retrospectivo. Rev Bras Cienc Saude. 2013;11(37):17-23.

5. Leal NFBS, Dias LAR, Carrara HHA, Ferreira CHJ. Linfedema pós-câncer de mama: comparação de duas técnicas fisioterapêuticas - estudo piloto. Fisioter Mov. 2011;24(4): 647-54.

6. Mendes B, Salomé GM, Pinheiro FAM, Massahud Jr MR, Cunha DR, Ferreira LM. Prevention and treatment of the trench foot: validation of a teaching manual for military personnel. J Wound Care. 2018;27(Sup10):S33-8.

7. Salomé GM, Bueno JC, Ferreira LM. Multimedia application in a mobile platform for wound treatment using herbal and medicinal plants. J Nurs UFPE on line. 2017;11(Suppl. 11):4579-88.
8. Santos AC, Dutra RAA, Salomé GM, Ferreira LM. Construction and internal reliability of an algorithm for choice cleaning and topical therapy on wounds. J Nurs UFPE on line. 2018;12(5):680-5

9. Cunha DR, Salomé GM, Massahud Jr MR, Mendes B, Ferreira LM. Development and validation of an algorithm for laser application in wound treatment. Rev Latino-Am Enferm. 2017;25:e2955.

10. Metcalf DG, Bowler PG, Hurlow J. A clinical algorithm for wound biofilm i dentification. J Wound Care. 2014;23(3):137-42.

11. Van LR, Beitz JM. Creating a pressure ulcer prevention algorithm: systematic review and face validation. Ostomy Wound Manag. 2013;59(11):28-40.

12. Cunha DR, Dutra RAA, Salomé GM. Construction of a multimedia application in a mobile platform for wound treatment with laser therapy. J Nurs UFPE on line. 2018;12(5):680-5.

13. Cunha JB, Dutra RAA, Salomé GM. Elaboration of an algorithm for wound evaluation and treatment. Estima, Braz. J Enterostomal Ther. 2018;16:e2018.

14. Cunha JB, Dutra RAA, Salomé GM, Ferreira LM. Computational system applied to mobile technology for evaluation and treatment of wounds. J Nurs UFPE on line. 2018;12(5):1263-72.

15. Agency for Health Care Research and Quality. Quality improvement and monitoring at your fingertips. Rockville: Agency for Healthcare Research and Quality; 2016.

16. Grant JS, Davis LL. Selection and use of contente experts for instrument development. Res Nurs Health.1997;20(3):269-74.

17. Cassiani SH, Rodrigues LP. A técnica de Delphi e a técnica de grupo nominal como estratégias de coleta de dados das pesquisas em enfermagem. Rev Acta Paul Enferm. 1996;9(3):76-83.

18. Wright JTC, Giovinazzo RA. Delphi - uma ferramenta de apoio ao planejamento prospectivo. Cad Pesq Admin. 2000;1(1):54-65. 
19. McGilton KS. Development and psychometric evaluation of supportive leadership scales. Can J Nurs Res. 2003;35(4):72-86.

20. Wind CA, Schmidt B, Schaefer MA. Two quantitative approaches for estimating content validity. West J Nurs Res. 2003;25(5):508-18.

21. Rezende LF, Brandino HE, Ciaco EF. Avaliação da eficácia das medidas preventivas do linfedema secundário ao tratamento cirúrgico do câncer de mama. Rev Bras Mastol. 2008;18(4):140-4.

22. Lacomba MT, Sanchez MJY, Goñi AZ, Merino, DP, Del Moral OM, Téllez EC, et al. Effectiveness of early physiotherapy to prevent lymphoedema after surgery for breast cancer: randomised, single blinded, clinical trial. BMJ. 2010;12(1):340-6.

23. Carvalho MRF, Salomé GM, Ferreira LM. Construction and validation of algorithm for treatment of pressure injury. J Nurs UFPE on line. 2017;11(Suppl 10):4171-83.
24. Brandão ES, Santos I, Clós AC. Dermatology nursing: sensitive listening skills and technology for acting in skin care. Rev Enferm UERJ. 2009;17(1):124-9.

25. Johnson JJ, Paustrian C. Guideline for management of wounds in patients with lower-extremity venous disease. Glenview: Wound Ostomy and Continence Nurses Society-WOCN; 2005.

26. Salomé GM, Cunha AL, Pereira AP, Miranda FD, Alves JR. Educational handbook for healthcare professionals: Preventing complications and treating Peristomal skin. J Coloproctol. 2019;39(4):332-8.

27. Fabro EAN, Costa RM, Oliveira JF, Lou MBA, Torres DM, Ferreira FO, et al. Atenção fisioterapêutica no controle do linfedema secundário ao tratamento do câncer de mama: rotina do Hospital do Câncer III/Instituto Nacional de Câncer. R Bras Mastologia. 2016;26(1):4-8.

28. Baracho E. Fisioterapia aplicada à saúde da mulher. Rio de Janeiro: Guanabara Koogan; 2018.

Received: 05/20/2020

Recebido: 20/05/2020

Approved: 08/03/2020

Aprovado: 03/08/2020 